\title{
Milk protein
}

\section{By P. С. Thомas, Hannah Research Institute, Ayr KA6 ${ }_{5} H L$}

Of the major organic constituents in milk, milk protein is arguably the most important, nutritionally and economically. Milk protein is of high biological value, it has none of the anti-nutritive factors often associated with high-protein foods of plant origin, it has good processing characteristics and is bland, making it useful for incorporation into a wide variety of food products for human consumption. The proportion of milk produced in Britain that is used for manufacturing is increasing year by year and a greater commercial emphasis is being placed on the milk protein. This paper is concerned specifically with that constituent and deals particularly with the relationship between the cow's nutrition and the content and composition of the protein in her milk.

\section{The protein constituents of milk}

Conventionally, milk 'total protein' is estimated as $6.38 \times$ total nitrogen content (this assumes that milk 'protein' contains $156.8 \mathrm{gN} / \mathrm{kg}$, although modern analysis suggests that $158.9 \mathrm{gN} / \mathrm{kg}$ might be a more appropriate figure). Of this 'protein' a small proportion is non-protein $\mathrm{N}$ but typically more than $94 \%$ is true protein. The largest component in the non-protein $\mathrm{N}$ fraction is urea which diffuses freely throughout body water so that the concentration of urea in milk is in equilibrium with that in blood plasma (see Thomas, 1980). The milk true protein is a mixture of caseins and milk serum or whey proteins. Most of the proteins present are synthesized in the mammary gland though there is a transfer of immunoglobulins and albumin from the blood. In early studies of the chemistry of milk, the proteins were routinely fractionated using precipitation techniques (Rowland, 1938; Aschaffenburg \& Drewry, 1959) to give, for example, casein, $\beta$-lactoglobulin, residual albumin (which is mainly $\alpha$-lactalbumin), globulin and a proteose-peptone component. Application of gel electrophoresis and gel chromatography techniques has more recently allowed fuller analyses to be made and coupled with this there have been determined efforts to rationalize and standardize nomenclature for both the major and minor protein components (see Brunner, 198I). The main components of the casein fraction are now regarded as $\alpha_{S_{1}-}, \alpha_{S_{2}-}, \beta-, \gamma-$ and $x$-caseins, whilst the milk serum proteins consist of $\beta$-lactoglobulin, $\alpha$-lactalbumin, bovine serum albumin, immunoglobulins and a proteose-peptone fraction. There is still disagreement in the literature about the exact proportions of the total protein that are accounted for by these various protein components, but this partly reflects methodological differences in analysis. Some recent analyses of the average content and composition of the protein in creamery milk samples are given in Table 1 , and these are probably typical of milks produced under British conditions. 
Table I. The content and composition of protein in creamery milks in South-rvest Scotland

(Values are means for twenty-nine samples obtained from five creameries and are taken from Davies \& Law (1980))

Total protein
Total casein
$\alpha_{\mathrm{S}_{1}}$-Casein
$\alpha_{\mathrm{S}_{2}}$-Casein
$\beta$-Casein
$\kappa$-Casein
$\gamma$-Casein
Milk serum proteins
$\beta$-Lactoglobulin
$\alpha$-Lactalbumin
Bovine serum albumin
Immunoglobulins, proteose-
peptone and lactoferrin

$\begin{array}{cc}\begin{array}{c}\text { Content in } \\ \text { skimmed milk } \\ (\mathrm{g} / \mathrm{l})\end{array} & \begin{array}{c}\text { Composition of } \\ \text { total protein } \\ (\mathrm{g} / \mathrm{kg})\end{array} \\ 32 \cdot 71 & - \\ 26.92 & 822 \\ 10.25 & 313 \\ 2.74 & 84 \\ 9.60 & 293 \\ 3.45 & 105 \\ 0.88 & 27 \\ 5.79 & 178 \\ 3.14 & 96 \\ 1.23 & 38 \\ 0.45 & 14 \\ 0.97 & 30\end{array}$

\section{Factors affecting milk protein content and composition}

Milk protein content is affected by nutritional and non-nutritional factors (see Rook, 1961). The latter, which include the breed, strain and individual characteristics of the animal, its age and stage of lactation, current and past mastitis infections and the frequency and completeness of milking, are outside the scope of this paper, but lactational changes are referred to later and will be briefly described.

Colostrum, the first secretion removed from the mammary gland at the start of lactation, has a characteristically high total protein content and a high proportion of immunoglobulins which persists for the first day or two of lactation. As lactation becomes established and milk yield rises, there is a reduction in total protein content which continues up to or beyond the lactational peak in milk yield. Thereafter, the protein content rises slowly, the rate of change accelerating after the $35^{\text {th }}$ week of lactation as milk yield begins to decline more steeply (Rook \& Campling, 1965). Lactational changes in the content of the individual protein components in milk follow closely those in total protein, though $\beta$-lactoglobulin is an exception in that its content rises to a peak in mid-lactation (Rook \& Campling, 1965).

\section{Nutrition and milk protein content and composition}

\section{Milk protein composition}

As far as the composition of milk protein is concerned, most of the present evidence indicates that changes in the cow's nutrition will produce only small effects, and mainly in the minor protein components. The proportion of nonprotein $\mathrm{N}$ in milk varies with the dietary protein content (Thomas, 1980) and there 
are indications that diet has a greater effect on the milk content of mammarysynthesized proteins than on bovine serum albumin (Yousef et al. 1970). However, in several experiments in which Aschaffenburg \& Drewry (1959) fractionations or more specific methods of protein analysis have been used, nutritional responses in milk total protein content have occurred without a significant alteration in the relative proportions of casein(s), $\beta$-lactoglobulin and $\alpha$-lactalbumin (Rook $\&$ Line, 1961 ; Chalmers \& Thomas, 1978; Bartsch et al. 1979; Grant \& Patel, r980). In one experiment, Yousef et al. (1970) reported dietary effects on the proportions of milk $\alpha-, \beta$ - and $\gamma$-caseins, $\beta$-lactoglobulin and $\alpha$-lactalbumin, but these results should be interpreted with caution. The observed effects did not occur consistently when milk protein content was improved through nutrition and the experimental design involved comparisons between small groups of animals, which may have allowed inherent differences in milk protein composition between animals to be expressed as treatment effects. Grimble ( $198 \mathrm{I})$ reported that in rats given a protein-deficient diet there was a specific reduction in the $a$-lactalbumin content of milk but there is no evidence of a similar effect in the cow. Thus, excepting the influence of diet on the milk non-protein $\mathrm{N}$ fraction, changes in nutrition appear to have a similar impact on all the major milk protein components so that nutritional responses in protein content can be satisfactorily described in terms of total protein.

\section{Physiological regulation of milk protein content}

Milk protein content is ultimately determined by the rates of secretion of protein and water from the alveolar secretory cells in the mammary gland. The output of water is in turn regulated by the secretion of the milk osmotic constituents-the milk ions (e.g. potassium, sodium and chloride) and lactose, especially (see Peaker \& Faulkner, 1983 ). Under most circumstances, lactose yield can be regarded as the determinant of milk water yield (Rook \& Hopwood, 1970) and thus in simplistic terms milk protein content depends on the relative rates of secretion of protein and lactose.

Protein synthesis in the mammary secretory cells (see Fig. I) involves the transfer of coded genetic information from the DNA of the nucleus to the polyribosome sites at the endoplasmic reticulum. There, under the direction of mRNA, rRNA and tRNA, the assembly of amino acids into proteins takes place. As the protein chains are formed and elongated, they are 'extruded' through the membrane and into the lumen of the endoplasmic reticulum and thence pass via the reticular microtubules to the Golgi apparatus where they are accumulated (see Mercier \& Gaye, 1982). The Golgi apparatus is also the site where lactose synthesis is initiated; lactose synthetase, the enzyme required for the formation of lactose from glucose and UDP-galactose, is formed through the combination of $\alpha$-lactalbumin with galactosyl transferase, a galactosylating enzyme found on the inner surface of the Golgi membrane (see Kuhn et al. 1980). Both the milk proteins and lactose are secreted from the cell by the same route. Vesicles bud off from the Golgi apparatus and pass to the apical surface of the cell where their contents are 


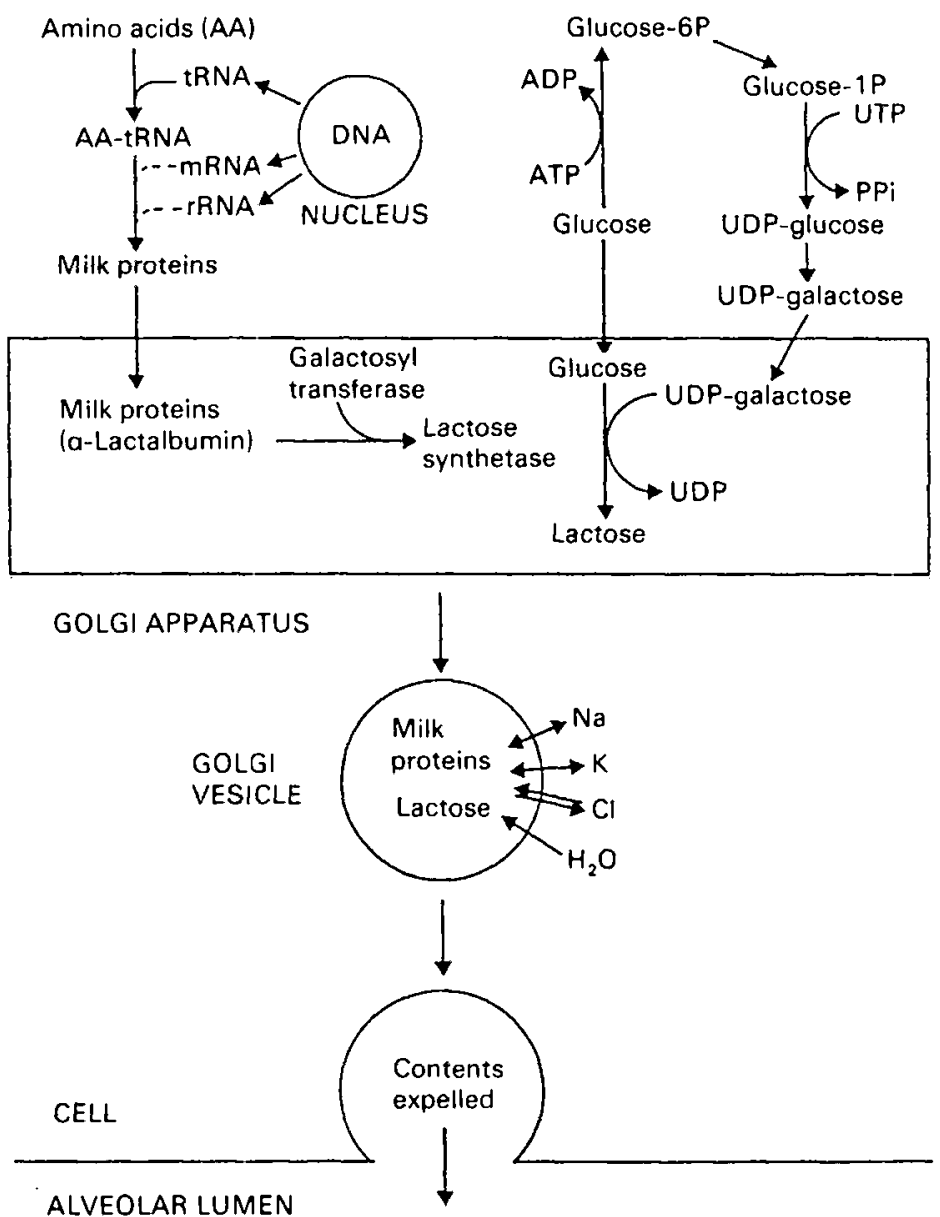

Fig. I. A schematic outline of the processes for the synthesis and secretion of milk protein and lactose in the secretory cells of the mammary gland.

expelled into the alveolar lumen. These vesicles contain the proteins and lactose, and in their passage through the cell are envisaged to swell and progressively to achieve the ionic composition of freshly secreted milk, unmodified by postsecretory paracellular exchanges with blood plasma (Peaker \& Faulkner, 1983).

The principal mechanisms regulating the synthesis of milk protein and lactose (both those operating at the cellular and the whole mammary gland level) remain to be clearly established. Recent reviews of the literature (Kuhn et al. 1980; Rook \& Thomas, 1980; Bines \& Hart, 1982; Kronfeld, 1982; Mepham, 1982) have served to re-emphasize the importance of the supply of precursor nutrients for product synthesis, the substantial cellular demand for ATP to support the intensive synthetic processes that are involved in milk secretion, and the potential hormonal influences both on nutrient supply and cellular metabolism. Several authors have also drawn attention to the link between $\alpha$-lactalbumin and lactose synthesis but, 
except in the lactogenic period, the rate of synthesis of a-lactalbumin seems unlikely to limit lactose synthetase activity (Kuhn et al. 1980). Hassan et al. (1982) have recently obtained evidence of intracellular degradation of newly synthesized casein in experiments with mammary cell cultures, but the contribution of such degradation to the regulation of milk protein secretion in vivo has yet to be ascertained.

In quantitative terms, the main nutrients in blood that are available to the mammary gland and are used for milk synthesis are amino acids, glucose, acetate, $\beta$-hydroxybutyrate, lactate and long-chain fatty acids, principally from the plasma triglycerides. The composition of this mixture represents the resultant effects of the uptake of products of digestion from the rumen and intestines, the modification of those products during absorption, and the synthesis and interconversion of metabolites in the liver and extra-hepatic tissues. The supply of these nutrients for milk synthesis varies with their concentration in arterial blood, with mammary blood flow and with the efficiency with which the individual nutrients are extracted by the gland. Application of arterio-venous difference methods and radioisotope techniques has allowed quantitative descriptions of some relationships between nutrient supply, uptake and utilization (for a general review see Rook \& Thomas, 1983).

The uptake of total amino acids is sufficient to account for the $\mathrm{N}$ and $\mathrm{C}$ secreted in milk protein but there are disparities in uptake and secretion for individual amino acids, and there is evidence of amino acid synthesis and oxidation in the gland. Mepham (1982) has provided a comprehensive review of the subject but it would be useful to summarize some key points briefly. The non-essential amino acids show variable uptakes with time throughout the day but on average a deficit in uptake relative to the amounts secreted in milk protein. In contrast, the essential amino acids (i.e. those that cannot be synthesized in the gland) are absorbed in amounts equal to or in excess of those secreted. On the basis of data for the goat and guinea-pig, Mepham (1982) has classified these two groups of essential amino acids as group I (methionine, histidine, phenylalanine, tyrosine and tryptophan) and group 2 (lysine, leucine, isoleucine, threonine, valine and arginine). However, data for the cow (Bickerstaffe et al. 1974; Spires et al. 1975) indicate that for this species lysine, and possibly leucine, isoleucine and threonine also, could fall into the group I category. The coefficients of extraction of amino acids from arterial blood plasma vary between amino acids over a range from 0.05 to 0.65 and in the cow are high $(0.55-0.65)$ for certain essential amino acids, e.g. methionine and lysine, and for glutamic acid. The significance of these high values is open to debate but it can be argued that they indicate a high demand for the acids relative to their arterial supply. Little is known about the detailed mechanisms or regulation of amino acid uptake by the gland though Baumrucker \& Pocius (1978) have reported the occurrence of the $\gamma$-glutamyl transpeptidase system of transport in mammary tissue and have shown that the enzyme exhibits a specificity for individual amino acids which parallels the extraction coefficients observed in vivo. Pocius et al. ( $\mathrm{r} 98 \mathrm{I}$ ) have also recently reported that there is a significant mammary 
uptake of glutathione from the red blood cells and that breakdown of this substance could make a significant and previously unsuspected contribution to the supply of cysteine, glycine and glutamic acid.

Of the glucose taken up by the mammary gland $60 \%$ or more is used for lactose synthesis, and about $85 \%$ of lactose synthesized is derived directly from glucose. Some glucose is also used for glycerol and amino acid synthesis but, because of limitations on the conversion of glucose to acetyl-CoA in mammary tissue, glucose contributes little to ATP production (see Read et al. 1977; Smith \& Taylor, 1977). Most of the ATP produced in the gland is derived from the oxidation of acetate with a small contribution from the oxidation of $\beta$-hydroxybutyrate and amino acids (Davis \& Mepham, 1976; Clark et al. 1978). Long-chain fatty acids are not normally used for oxidation though they may contribute during underfeeding or when the cow is in negative energy balance, as in early lactation (Kronfeld, 1965; Linzell, 1967 ).

\section{Nutrient supply and milk protein content}

For the relationships between nutrient supply and the mammary secretory processes to be established satisfactorily requires those processes to be perturbed by nutritional or physiological manipulations that alter the balance between nutrient supply and demand. A technique widely used for this purpose has been the enteral or parenteral infusion of specific nutrient supplements in cows receiving a basal diet providing a defined level of nutrition. On the face of it, this approach seems ideal and some of the results that have been obtained are summarized below. However, it should be pointed out that the interpretation of the results is not without problems. First, there can be crucially important interactions between the infused nutrient(s) and the nutrient mixture derived from the basal diet selected. Second, responses to infusion can arise indirectly through effects on the secretion of hormones such as insulin, glucagon and growth hormone that have central roles in the general regulation of the cow's metabolism and/or influence mammary blood flow (Mepham, 1982).

Protein and amino acid infusions. Lactational responses to the intra-abomasal infusion of protein have been extensively studied in the dairy cow, the various experiments involving a range of ration types and dietary crude protein levels from I 10 to $240 \mathrm{~g} / \mathrm{kg}$ dry matter. The infusion treatments have consistently resulted in an improvement in milk protein content averaging about $5 \%$ (Fig. 2) and generally in an increase in milk yield. Experiments in which appropriate determinations have been made have shown that little of the response in milk protein is related to an increase in milk non-protein $\mathrm{N}$ content. The protein most commonly used for infusion has been casein but lactalbumin (Trigg et al. I982) and a mixture of ten essential amino acids (Schwab et al. 1976) has been infused with similar results. This suggests that the response in milk protein content probably relates to the improvement in amino acid supply. In some of the experiments with casein infusions, growth hormone secretion has been stimulated (see Gow et al. 1979) but 


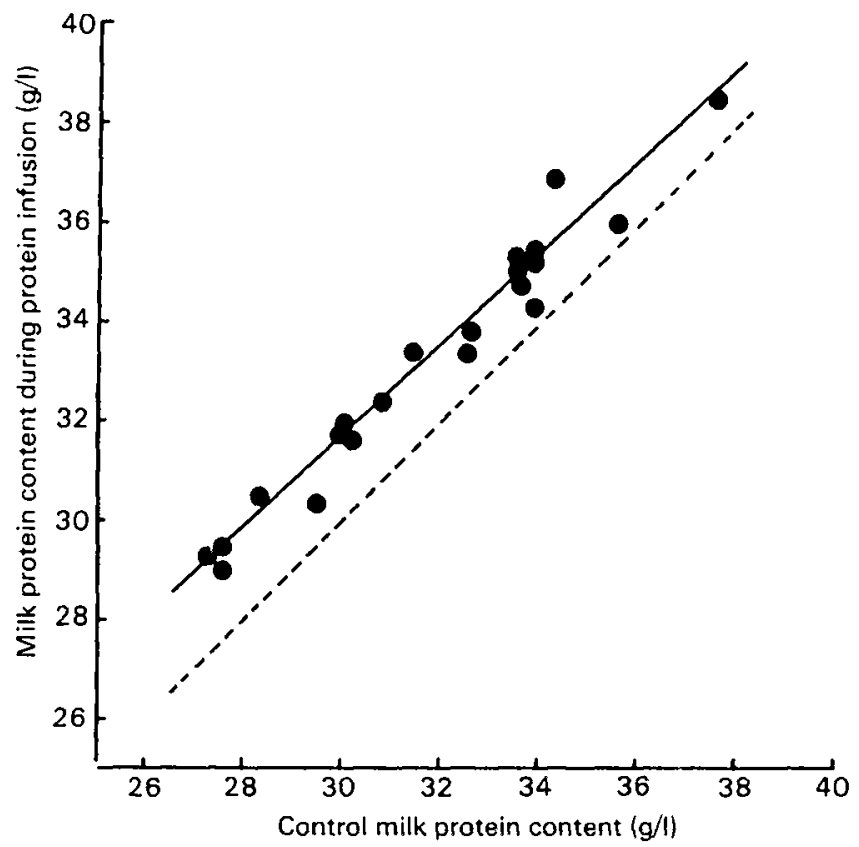

Fig. 2. The effect of intra-abomasal infusions of protein on milk protein content in cows receiving a range of diets. (The broken line represents the line of equality. The solid line represents the regression equation $Y=3.87+0.928 X(r 0.98 ; n 21)$ derived from the experimental observations. Results are taken from Broderick et al. (1970), Derrig et al. (1974), Vik-Mo et al. (1974), Schwab et al. (1976), Clark et al. (1977) and Trigg et al. (1982).

growth hormone itself does not increase milk protein content (Bines et al. 1980; Peel et al. 198r).

Intra-abomasal and intravenous infusions of single amino acids (particularly methionine and lysine) or simple mixtures of amino acids have also been undertaken (see Clark, 1975; Schwab et al. 1976; Chamberlain \& Thomas, 1982). Methionine or lysine infused alone has been without effect on milk protein content but Schwab et al. (1976) found that methionine plus lysine alone or in combination with other essential amino acids produced a response equal to approximately $65 \%$ of that obtained with casein.

Glucose infusions. Intra-abomasal or intravenous infusions of glucose in dairy cows have produced small, statistically non-significant reductions in milk protein content (Fisher \& Elliot, 1966; Vik-Mo et al. 1974; Clark et al. 1977; Frobish \& Davis, 1977).

Volatile fatty acid infusions. Rook \& Balch (196r) first demonstrated effects of intraruminal infusions of volatile fatty acids on milk secretion in cows given basal diets of hay and dairy concentrates. Those experiments, together with later similar studies, showed that for milk protein content there was no response with infusions of butyric acid, a slight reduction with infusions of acetic acid and a significant increase, averaging about $5 \%$ of the control value, with infusions of propionic acid (for a summary of the experiments see Thomas \& Rook, 1977). Responses to 
propionic acid have not been obtained under all circumstances, however; intraruminal infusions in cows given diets of grass silage and dairy concentrates were without effect (Chalmers et al. 1980). Similarly, milk protein content was not increased by supplements of propionate given intra-abomasally (Frobish \& Davis, 1977) or intravenously (Fisher \& Elliot, 1966), although it must be recognized that both routes of administration are unphysiological.

The mechanism through which propionic acid can enhance milk protein content is unknown. Halfpenny et al. (1969) hypothesized that there were limitations on the rate of intramammary synthesis of glutamic acid and that propionate, through its conversion in the liver, could increase the arterial supply of glutamate to the gland. Mepham (1976) argued against this idea on the basis that short-term intraarterial infusions of a mixture of amino acids containing glutamate did not increase milk protein synthesis, and his case is supported by results from the intraabomasal infusion experiments of Schwab et al. (1976). Moreover, there are features of the response to propionic acid that suggest that it does not derive simply from the removal of a precursor limitation on milk protein synthesis. First, the response in protein synthesis is slow to develop, taking 6-10 d to become fully established. Second, examination of the infusion studies of Rook \& Balch (196r) in terms of the effects of the volatile acids on milk protein yield shows that both propionate and acetate have similar effects. The difference between the acids in their influence on milk protein content arises because acetic acid stimulates the synthesis of lactose; and thus with acetic acid the increase in protein yield is associated with a parallel change in the yield of milk water.

Propionic acid is a potent insulin secretagogue (Trenkle, 1978) but there is no evidence that insulin has an effect on milk protein content until its circulating levels are sufficient to depress blood glucose concentration substantially and limit lactose synthesis (Rook \& Hopwood, 1970; P. C. Thomas, S. Robertson and D. G. Chamberlain, unpublished results).

\section{Effects of diet amount and composition on milk protein content}

Individual experiments demonstrate very marked changes in milk protein content in response to alterations in the cow's feeding; increases as great as $8 \mathrm{~g} / 1$ have been reported, representing an improvement of $25 \%$ of the average protein value. More typically, however, increases are relatively small, around $4-6 \%$. Rook (1961) and Kirchgessner et al. (1967) have comprehensively reviewed early studies of the effects of the amount and composition of the diet on milk protein content and, more recently, various aspects of the subject have been discussed by Broster (1972), Rook (1976), Oldham \& Sutton (1979), Kaufman (1980), Thomas (1980) and Clark \& Davis (1980); Emery ( 1978 ) has also made a useful statistical analysis of relevant feeding experiments conducted in North America. The favoured approach has been to consider dietary protein effects and dietary energy effects separately, but this is largely a matter of convenience. Distinctive differences in the causal mechanisms underlying the various responses in milk protein content are not necessarily implied, and the potential for interactions between dietary protein 
and energy constituents during digestion in the rumen and during the metabolism of digestion end-products in the cow's tissues are well recognized.

Dietary protein supply. The results of the early feeding experiments led to the view that whilst milk yield and protein yield were altered by dietary protein supply, effects on milk protein content (excluding non-protein $\mathrm{N}$ content) were small. In many of the experiments changes in milk composition were barely apparent although there was clear evidence that protein content was reduced in the milk of cows subjected to severe protein undernutrition. In contrast to this, several recent experiments have shown milk protein content to be increased by up to $6 \%$ through alterations in the amount and/or type of protein in the diet (Majdoub et al. 1978; Van Horn et al. 1979; Ørskov et al. 1981; P. C. Thomas, S. Robertson and D. G. Chamberlain, unpublished results) and is it clear that the earlier ideas about the effect of dietary protein supply on milk protein content require revision. Where responses in milk protein content occur it seems likely that they relate to the precise impact of the change in dietary protein supply on the passage of amino acids to the small intestine. This is suggested by the results shown in Fig. 2 and is consistent with the fact that the effects on milk protein content are most commonly observed where dietary protein supplements are of low rumendegradability.

Dietary energy supply. It has been known for many years that milk protein content may be increased through an improvement in the 'plane of energy nutrition', a term coined specifically to describe an improvement in energy supply achieved through allocation of additional starchy concentrates to the cow (see Rook \& Line, 196r). Such a change in diet involves not only an increase in metabolizable energy (ME) intake but also a reduction in the dietary forage: concentrate value and substantial changes in the chemical composition of the diet. Few experiments have been conducted which allow the effects of ME intake per se to be separated from those of other diet characteristics but the limited information available suggests that $\mathrm{ME}$ intake, forage:concentrate value, type of forage (e.g. hay or silage) and type of concentrate (e.g. barley or maize) all can make a contribution to the milk protein response (Sutton et al. 1979; Thomas et al. 1980).

Uncertainties surround the 'plane of energy nutrition' effects, however, because they are variable in both occurrence and size. Some of the variability may relate to interactions between the level of energy nutrition and the normal lactational changes in protein content; for example, underfeeding in early-lactation tends to slow the lactational changes whilst in late-lactation it has an accelerating effect (Wright et al. 1974; Thomas \& Kelly, 1976). Nonetheless, this is only part of the story because, even in mid-lactation experiments, additional concentrate supplements by no means always increase milk protein content (Wright et al. 1974; Grant \& Patel, I980; Thomas et al. 1980). It has been reasoned that 'plane of energy nutrition' effects operate through the influence of starchy concentrates on propionate production in the rumen, and that the variability in milk protein response could relate to the failure of additional concentrates to alter the rumen fermentation pattern with certain types of diet. This explanation is not entirely 
convincing, however. As indicated earlier, responses even to ruminally-infused propionic acid are not invariably obtained. Moreover, in animals given highconcentrate diets where small changes in diet can be used to achieve marked differences between dietary treatments in the proportion of propionate in the rumen, there is no close relationship between milk protein content and ruminal propionate production (Yousef et al. 1970; Rogers et al. 1982).

Energy intake can also be increased through the dietary inclusion of fats and oils. These substances again have variable influences on milk protein, the content being unaffected or reduced (for references see Palmquist \& Moser, $198 \mathrm{r}$; Banks et al. 1983); the cause(s) of reductions where they occur is unknown. Effects of the added lipids on microbial fermentation and protein synthesis in the rumen could provide a partial explanation, but milk protein content has also been affected in cows given 'protected' lipid supplements and that suggests that the lipids have an action at the tissue level, possibly through their influence on the secretion of circulating hormones (Palmquist \& Moser, r98I).

\section{Conclusions}

From the foregoing discussion it is clear that whilst the amount and composition of the cow's diet has relatively little influence on the composition of milk protein it can influence milk protein content in a variety of ways. The mechanisms underlying these effects are still poorly understood and although the main biochemical and physiological features of protein, lactose and water secretion in milk have been described, little is known about the nutritional and hormonal regulation of the secretory processes. The results of dairy-cow-feeding experiments indicate that milk protein content can be increased by giving the cow more ME, more starchy concentrates and more protein concentrates of low rumen-degradability. However, a feature of the experiments is the variability and inconsistency of the responses to dietary change. This frustrates attempts to rationalize the effects and prevents satisfactory quantitative prediction of the result of any given change in diet.

\section{REFERENCES}

Aschaffenburg, R. \& Drewry, J. (1959). Proc. 5th Int. Dairy Congr., London, vol. 3, p. 1631. Banks, W., Clapperton, J. L. \& Steele, W. (1983). Proc. Nutr. Soc. 42, 399.

Bartsch, B. D., Graham, E. R. B. \& McLean, D. M. (1979). Aust. f. Agric. Res. 30, 191.

Baumrucker, C. R. \& Pocius, P. A. (1 978). F. Dairy Sci. 6r, 309.

Bickerstaffe, R., Annison, E. F. \& Linzell, J. L. (1974). J. agric. Sci., Camb. 82, 71.

Bines, J. A. \& Hart, I. C. (1982). F. Dairy Sci. 65, 1375.

Bines, J. A., Hart, I. C. \& Morant, S. V. (1980). Br. F. Nutr. 43, 179.

Broderick, G. A., Kowalczyk, T. \& Satter, L. D. (1970). f. Dairy Sci. 53, 714 .

Broster, W. H. (1972). In Handbuch der Tierernahrung, vol. 2, p. 271 [W. Lenkeit, K. Brierem and E. Craseman, editors]. Hamburg: Paul Parey.

Brunner, J. R. (1981). J. Dairy Sci. 64, 1038.

Chalmers, J. S. \& Thomas, P. C. (1978). Proc. roth Int. Dairy Congr., p. 59.

Chalmers, J. S., Thomas, P. C. \& Chamberlain, D. G. (1980). Proc. Nutr. Soc. 39, 27 A.

Chamberlain, D. G. \& Thomas, P. C. (1982). Y. Dairy Res. 49, 25.

Clark, J. H. (1975). J. Dairy Sci. 58, 1178 . 
Clark, J. H. \& Davis, C. L. (I g80). F. Dairy Sci. 63,873.

Clark, J. H., Spires, H. R. \& Davis, C. L. (1978). Fedn Proc. Fedn Am. Socs exp. Biol. 37, 1233.

Clark, J. H., Spires, H. R., Derrig, R. G. \& Bennink, M. R. (1977). F. Nutr. 107, 631.

Davies, D. T. \& Law, A. J. R. (1980). F. Dairy Res. 47, 83 .

Davis, S. R. \& Mepham, T. B. (1976). Biochem. f. 156, 553.

Derrig, R. G., Clark, J. H. \& Davis, C. L. (1974). F. Nutr. 104, 151 .

Emery, R. S. (1978). Y. Dairy Sci. 61, 825.

Fisher, L. J. \& Elliot, J. M. (1966), f. Dairy Sci. 49,826 .

Frobish, R. A. \& Davis, C. L. (1977). F. Dairy Sci. 60, 204.

Gow, C. B., Ranawana, S. S. E., Kellaway, R. C. \& McDowell, G. H. (1979). Br. F. Nutr. 41, 37 I.

Grant, D. R. \& Patel, P. R. (1980). F. Dairy Sci. 63, 756.

Grimble, R. (198I). Ann. Nutr. Metab. 25, 221.

Halfpenny, A. F., Rook, J. A. F. \& Smith, G. H. (1969). Br. F. Nutr. 23, 547.

Hassan, H. R., White, D. A. \& Mayer, R. J. (1982). Biochem. F., Cellular Aspects 202, 133.

Kaufman, W. (1980). Doc. 125, Int. Dairy Fed., Brussels, p. 152.

Kirchgessner, M., Friesecke, H. \& Koch, G. (1967). Nutrition and the Composition of Milk. London: Crosby Lockwood.

Kronfeld, D. S. (1965). Vet. Rec. 77, 30.

Kronfeld, D. S. (I982). F. Dairy Sci. 65, 2204.

Kuhn, N. J., Carrick, D. T. \& Wilde, C. J. (1980). Y. Dairy Sci. 63, 328.

Linzell, J. L. (1967). Y. Physiol., Lond. 190, 333.

Majdoub, A., Lane, G. T. \& Aitchison, T. E. (1978). J. Dairy Sci. 6r, 59.

Mepham, T. B. (1976). In Principles of Cattle Production, p. 201 [H. Swan and W. H. Broster, editors\}. London: Butterworths.

Mepham, T. B. (1982). J. Dairy Sci. 65, 287.

Mercier, J. C. \& Gaye, P. (1982). F. Dairy Sci. 65, 299.

Oldham, J. D. \& Sutton, J. D. (1979). In Feeding Strategy for the High Yielding Cow, P. II 4 [W. H. Broster and H. Swan, editors]. London: Granada Publishing.

Ørskov, E. R., Reid, G. W. \& McDonald, I. (1981). Br. F. Nutr. 45, 547.

Palmquist, D. L. \& Moser, E. A. (rg81). F. Dairy Sci. 64, 1664.

Peaker, M. \& Faulkner, A. (1983). Proc. Nutr. Soc. 42, 4 ig.

Peel, C. J., Bauman, D. E., Gorewit, R. C. \& Sniffen, C. J. (1981). F. Nutr. x11, 1662.

Pocius, P. A., Clark, J. H. \& Baumrucker, C. R. (1981). F. Dairy Sci. 64, 155 r.

Read, G., Crabtree, B. \& Smith, G. H. (1977). Biochem. f. 164, 349.

Rogers, J. A., Davis, C. L. \& Clark, J. H. (1982). F. Dairy Sci. 65, 577.

Rook, J. A. F. (1961). Dairy Sci. Abstr. 23, 251.

Rook, J. A. F. (1976). In Principles of Cattle Production, p. $22 \mathrm{I}$ [H. Swan and W. H. Broster, editors]. London: Butterworths.

Rook, J. A. F. \& Balch, C. C. (1961). Br. Y. Nutr. 15, 361.

Rook, J. A. F. \& Campling, R. C. (1965). f. Dairy Res. 32, 45.

Rook, J. A. F. \& Hopwood, J. B. (1970). Y. Dairy Res. 37, 193.

Rook, J. A. F. \& Line, C. (1961). Br. F. Nutr. 15, 109.

Rook, J. A. F. \& Thomas, P. C. (1980). Doc. 125, Int. Dairy Fed., Brussels, p. 66.

Rook, J. A. F. \& Thomas, P. C. (1983). In Nutritional Physiology of Farm Animals, p. $3^{14}$ [J. A. F. Rook and P. C. Thomas, editors]. London: Longmans.

Rowland, S. J. (1938). F. Dairy Res. 9, $4^{2}$.

Schwab, C. G., Satter, L. D. \& Clay, A. B. (1976). J. Dairy Sci. 59, 1254.

Smith, G. H. \& Taylor, D. J. (1977). In Comparative Aspects of Lactation, p. 95 [M. Peaker, editor]. London: Academic Press.

Spires, H. R., Clark, J. H., Derrig, R. G. \& Davis, C. L. (1975). f. Nutr. 105, I I I.

Sutton, J. D., Oldham, J. D. \& Hart, I. C. (1979). In Energy Metabolism, p. 303 [L. Mount, editor]. London: Butterworths.

Thomas, P. C. (1980). Doc. 125, Int. Dairy Fed., Brussels, p. $14^{2}$.

Thomas, P. C., Chalmers, J. S., Chamberlain, D. G. \& Belibasakis, N. (1980). In Proc. 3rd Eur. Assoc. Anim. Prod. Symp. Protein Metab. Nutr., vol. II, p. 522 [H. J. Oslage and K. Rohr, editors]. Braunschweig: Information Centre of Bundesforschungsanstalt fur Landwirtschaft. 
Thomas, P. C. \& Kelly, M. E. (1976). J. Dairy Res. 43, I.

Thomas, P. C. \& Rook, J. A. F. (1977). In Recent Advances in Animal Nutrition-1977, p. 83 [W. Haresign and D. Lewis, editors]. London: Butterworths.

Trenkle, A. (1978). 7. Dairy Sci. 6r, 281.

Trigg, T. E., Parr, C. R., Day, A. M. \& Parsons, B. W. (1982). In Energy Metabolism of Farm Animals, p. $4^{2}$ [A. Ekern and F. Sundstøl, editors]. Aas, Norway: Agricultural University of Norway.

Van Horn, H. H., Zometa, C. A., Wilcox, C. J., Marshall, S. P. \& Harris, B. Jr (1979). J. Dairy Sci. 62, 1086.

Vik-Mo, L., Emery, R. S. \& Huber, J. T. (1974). F. Dairy Sci. 57, 869.

Wright, J. A., Rook, J. A. F. \& Wood, P. D. P. (I974). F. Dairy Res. 4I, 155.

Yousef, I. M., Huber, J. T. \& Emery, R. S. (1970). f. Dairy Sci. 53, 734. 